\title{
Sebaran Suhu Buah Terung Belanda (Chyphomandra betacea) pada Berbagai Tingkat Kematangan Selama Proses Pendinginan (Hydrocooling)
}

\author{
Fransiska $^{1}$, Supratomo $^{1}$ dan Faridah ${ }^{1}$ \\ Program Studi Teknik Pertanian, Universitas Hasanuddin Makassar
}

\begin{abstract}
ABSTRAK
Terung belanda (Cyphomandra betacea) merupakan salah satu tanaman tropik yang memiliki kandungan gizi yang tinggi. Kurangnya perhatian akan penanganan pasca panen pada produk pertanian menyebabkan kemunduran mutu dan berkurangnya nilai jual produk. Salah satu upaya yang dapat dilakukan untuk mempertahankan mutu pada produk pertanian dengan menekan laju respirasi dan transpirasi melalui precooling. Pada penelitian ini dilakukan penanganan pasca panen pada buah terung belanda berupa precooling dengan sistem hydrocooling yang bertujuan untuk mempelajari sebaran suhu, pengaruh hydrocooling terhadap sifat fisik dan laju pendinginan pada buah. Parameter yang diamati adalah sebaran suhu, bobot dan laju pendinginan. Laju pendinginan komersial yang diterapkan pada produk pertanian digambarkan dengan 7/8 waktu pendinginan.

Berdasarkan penelitian yang dilakukan, dapat diketahui bahwa distribusi suhu dari permukaan hingga pusat buah untuk mencapai suhu pendinginan pada buah mengkal membutuhkan waktu selama 43 menit, matang optimal selama 56 menit dan matang berlebih selama 36 menit. Untuk mencapai suhu 7/8 waktu pendinginan membutuhkan waktu selama 51 menit pada buah mengkal, buah matang optimal selama 48 menit dan buah matang berlebih selama 42 menit. Sehingga laju pendinginan pada buah akan semakin cepat tercapai seiring kematangan pada buah.
\end{abstract}

Kata kunci: Hydrocooling, Sebaran suhu, Pendinginan 7/8, Terung belanda.

\section{PENDAHULUAN}

\section{Latar Belakang}

Indonesia merupakan salah satu negara yang memiliki potensi yang besar di bidang pertanian ditinjau dari letak geografis, iklim serta sumber daya yang besar. Namun potensi tersebut belum diupayakan secara maksimal hal ini disebabkan oleh penanganan pasca panen yang belum tepat sehingga menyebabkan buah yang sampai pada konsumen mengalami penurunan kualitas yang berdampak pada berkurangnya penghasilan petani.

Salah satu buah tropik yang memiliki potensi besar adalah buah terung belanda (Chypomandra betacea) karena memiliki kandungan nutrisi tinggi yang baik bagi kesehatan, sehingga banyak diminati oleh masyarakat. Tanaman ini tumbuh pada dataran tinggi dan berkembang dengan baik pada daerah yang sejuk. Buah ini termasuk dalam kelompok buah non klimaterik sehingga waktu panen perlu diperhatikan. Salah satu indikator penentuan waktu panen yang umum digunakan adalah kenampakan visual atau warna. Selain itu faktor yang perlu dipertimbangkan adalah sifat fisik dan kimia buah, hal ini sangat penting dalam perhitungan energi untuk pendingan, pengeringan, rancang alat, distribusi, penyimpanan dan lain sebagainya.

Buah yang telah dipanen masih mengandung panas lapangan (field heat) akibat proses metabolisme dari buah tersebut yang dicirikan dengan terjadinya proses respirasi dan transpirasi. Hal ini berdampak pada kemunduran mutu produk seperti pelayuan, kehilangan air, berkurangnya cita rasa dan pertumbuhan mikroorganisme. Salah satu upaya yang dapat dilakukan dalam menekan laju respirasi adalah pengendalian lingkungan berupa pendinginan. Suhu yang rendah akan memperlambat proses metabolisme pada produk, sebelum dilakukan pendinginan perlu diketahui karasteristik dari bahan baik 
karasteristik fisik maupun kimia hal ini bertujuan untuk menghindari kerusakan dingin (chilling injury) akibat suhu yang terlalu rendah.

Pengelolaan suhu dapat dibagi menjadi dua fase. Pertama adalah fase precooling yakni pendinginan untuk melepaskan panas lapang dan kedua adalah fase penyimpanan pada suhu dingin dimana kelembaban juga turut diperhitungan. Salah satu teknik precooling yang dapat digunakan adalah hydrocooling yang menggunakan air sebagai media (coolant) karena karena memiliki daya penghantar yang baik dalam perpindahan suhu atau laju pendinginan, selain itu penggunaan air dan es lebih ekonomis di kalangan petani.

Berdasarkan uraian tersebut maka dilakukan penelitian penanganan pasca panen pada buah terung belanda yang mencakup perlakuan pendinginan secara cepat pada kondisi precooling dengan menggunakan teknik pendinginan hydrocooling pada berbagai tingkat kematangan.

\section{Tujuan dan Kegunaan}

Adapun tujuan dari penelitian ini adalah sebagai berikut.

1. Mempelajari sebaran suhu pada buah terung belanda (Chypomandra betacea) menggunakan teknik pendinginan hydrocooling pada berbagai tingkat kematangan.

2. Mempelajari pengaruh hydrocooling terhadap sifat fisik buah.

3. Menentukan waktu pendinginan $7 / 8$ pada buah terung belanda dengan berbagai tingkat kematangan.

Kegunaan dari penelitian ini adalah sebagai bahan informasi tentang pengaruh pendinginan hydrocooling pada buah terung belanda dengan berbagai tingkat kematangan untuk mempertahankan mutu buah dan acuan untuk penanganan lebih lanjut.

\section{TINJAUAN PUSTAKA}

\section{Terung belanda (Chiphomandra betaceae)}

Terung belanda (Chiphomandra betaceae) dapat tumbuh di daerah tropik pada ketinggian 1000 hinga 2000 mdpl pada kisaran suhu $10^{\circ} \mathrm{C}$. Buah dapat dipanen setelah mencapai umur 60 hingga 90 hari setelah masa pembuahan (Tarigan, 2006).

Terung belanda (Chiphomandra betaceae) berupa tanaman perdu yang memiliki ketinggian 2-3 m, memiliki pangkal batang pendek dan cabang yang lebat serta daun yang berada di ujung pucuk dengan panjang 10-35 cm dan lebar 4-20 cm. Buah berbentuk oval dengan diameter kurang lebih $4 \mathrm{~cm}$, berwarna merah, jingga dan kuning, Kulit buah tipis dan memiliki biji berbentuk bulat pipih, tipis dan keras serta rasa daging buah agak masam (Kumalaningsih, 2006).

Buah terung belanda terdiri dari tiga bagian, yaitu kulit, daging dan biji. Terdiri dari $13 \%$ kulit, $67 \%$ bagian daging buah serta 20\% merupakan bagian dari biji. Daging buah berwarna kuning cerah kemerahan sedangkan biji berwarna merah keunguan. Menurut Kumalaningsih (2006), fungsi dari kulit terung belanda dapat dijadikan sebagai bahan pewarna alami.

Terung belanda termasuk buah non klimaterik dimana metabolisme pada buah berlangsung secara lambat sehingga tidak terjadi pematangan pada buah ketika sudah terlepas dari pohonnya. Oleh karena itu indeks kematangan buah dan waktu pemanenan. Dengan memperhatikan indeks kematangan pada buah berdasarkan standar panen maka akan mengurangi susut saat pre-sortasi.

Komposisi kimia yang terkandung di dalam terung belanda menurut Verheij dan Coronel (1997) dapat dilihat pada tabel berikut :

Tabel 1. Komposisi Kimia Terung belanda dalam 100 gram Bahan

\begin{tabular}{|l|c|}
\hline Komposisi & Jumlah $(\mathrm{gr})$ \\
\hline Air & 85,00 \\
\hline Protein & 1,50 \\
\hline Lemak & $0,06-0,028$ \\
\hline Karbohidrat & 10,00 \\
\hline Serat & $1,40-4,20$ \\
\hline Abu & 0,70 \\
\hline Vit A $(\mathrm{SI})$ & $150-1500$ \\
\hline Vit C $(\mathrm{Mg})$ & 25,00 \\
\hline
\end{tabular}


Sumber : Verheij dan Coronel (1997).

Terung belanda mengandung provitamin A untuk kesehatan mata, vitamin $\mathrm{C}$ dan kandungan mineral seperti fosfor, potasium dan magnesium mampu menjaga dan meningkatkan daya tahan tubuh disamping buah ini kaya akan serat yang tinggi dan antosianin yang merupakan salah satu antioksidan penangkal radikal bebas untuk mencegah kanker (Kumalaningsih, 2006).

\section{Penanganan Pasca Panen}

Kegiatan pasca panen merupakan rangkaian kegiatan setelah panen yang dilaksanakan dalam tahapan dan waktu yang sesingkat mungin untuk mendistribusikan produk hasil pertanian dari lahan produksi ke tangan konsumen. Penanganan pasca panen diharapkan mampu mengurangi kehilangan dan kerusakan serta meningkatkan daya saing produk tersebut (Utama, 2007).

Faktor-faktor yang perlu diperhatikan dalam penanganan pasca panen antara lain suhu, kelembaban, kadar air, kandungan nutrisi, dan keamanan pangan. Penanganan panen dan pasca panen untuk masing-masing komoditas bersifat spesifik sesuai dengan karakter khusus, segmen pasar yang dituju, waktu tempuh dan selera konsumen. Faktor pembeda penanganan pasca panen yaitu indeks kematangan, metode panen, cara pengemasan, cara penanganan produk di kebun dan di bangsal pasca panen, kepekaan terhadap etilen, pengaturan suhu dan kelembaban selama penyimpanan dan transportasi. Faktor-faktor pembeda tersebut berpengaruh terhadap prosedur penanganan panen dan pasca panen (Utama, 2007).

Hal-hal yang perlu dipertimbangkan pada proses penanganan pasca panen adalah pertimbangan fisiologis khususnya laju metabolisme pada produk pasca panen. Pertimbangan patologis berupa mikroorganisme penyebab pembusukan pada buah dan pertimbangan ekonomis, sebagian besar teknologi yang dikembangkan di negara maju tidak dapat diterapkan di negara berkembang seperti
Indonesia yang sebagian besar petaninya berskala kecil dan menengah akibat kurangnya akses pasar yang bernilai lebih bagi petani (Utama 2000).

Menurut Permentan (2013), Penanganan buah dilakukan untuk tujuan penyimpanan, transportasi hingga pemasaran. Adapun kegiatan pasca panen meliputi :

a. Bongkar-muat

b. Sorting

c. Pembersihan

d. Precooling

e. Pelapisan (coating)

f. Curing

g. Degreening

h. Grading

i. Pengemasan dan pelabelan

\section{Teknik Pendinginan}

Buah pasca panen akan mengalami stress dan mengalami proses metabolisme untuk mepertahankan hidup. Sehingga dibutuhkan proses pendinginan secara cepat dilapangan. Mikroorganisme penyebab pembusukan pada buah dapat dikendalikan dengan suhu rendah. Setiap peningkatan suhu sebesar $10^{\circ} \mathrm{C}$ akan meningkatkan laju kemunduran dua hingga tiga kali atau lebih produk hasil pertanian tergantung pada jenis produk.

Menurut Winarno (1982), pada kondisi suhu yang rendah dapat memperlambat kecepatan reaksi-reaksi metabolisme, dimana pada umumnya setiap penurunan suhu sebesar $8^{\circ} \mathrm{C}$ maka kecepatan reaksi akan berkurang kira-kira setengahnya. Semakin rendah suhu maka proses metabolisme pada buah akan semakin rendah. Suhu yang terlalu rendah dapat menimbulkan kerusakan dingin (chilling injury).

Pengelolaan suhu dapat dibagi menjadi dua fase. Pertama adalah fase pendinginan untuk melepaskan panas lapang (precooling) dan kedua adalah menjaga produk pada suhu optimum selama pendistribusiannya. Kebanyakan produk, terutama yang mempunyai laju respirasi tinggi. 
Precooling yaitu pendinginan cepat untuk mengambil panas sensibel (field heat) sebelum produk mengalami transportasi atau penyimpanan. Suhu produk diturunkan dalam waktu beberapa menit atau beberapa jam, sehingga produk tetap segar. Precooling bertujuan menurunkan aktivitas metabolisme pada produk pasca panen yakni laju respirasi dan produksi gas etilen (Etan et al., 2002).

Precooling berbeda dari coldstorage yang suhunya sudah ditetapkan sebelumnya.Pada proses precooling komersial, produk di precooling hingga suhunya mencapai $7 / 8$ kali perbedaan suhu lapang dan suhu akhir yang diinginkan (1/8 sisa suhu hilang pada saat transportasi atau penyimpanan dingin). Pada metode precooling diusahakan agar suhu sebisa mungkin mendekati suhu penyimpanan produk.

Tabel 2. Toleransi suhu yang dapat diterima oleh buah.

\begin{tabular}{|c|c|c|c|c|c|}
\hline \multicolumn{2}{|c|}{$32-36^{\circ} \mathrm{F}, 0-2^{\circ} \mathrm{C}$} & \multicolumn{2}{|c|}{$45-50^{\circ} \mathrm{F}, 7-10^{\circ} \mathrm{C}$} & \multicolumn{2}{|c|}{$55-65^{\circ} \mathrm{F}, 13-18^{\circ} \mathrm{C}$} \\
\hline \multicolumn{6}{|c|}{ Fruits } \\
\hline Apple & Fig & Avocado & Orange & Atemoya & Mango \\
\hline Quince & Goosseberry & Pear & Olive & Banana & Mangosteen \\
\hline Apricot & Grape & Carambola & Orange & Breadfruit & Papaya \\
\hline Raspberry & Kiwifruit* & Chayote & Passion Fruit & Cherimoya & Plantain \\
\hline Avocado & Nectarine & Cranberry & Pepino & Coconut & Pummelo \\
\hline Ripe & Peach & Feijoa & Pineapple & Grapefruit* & Rambutan \\
\hline Strawberry & Pear; Asian & Guava & Pomegranate & Lemon* & Sapote \\
\hline Blackberry & $\begin{array}{l}\text { Pear; } \\
\text { European }\end{array}$ & Kumquat & Tamarillo & Lime* & Soursop \\
\hline Cherry & Plum & Lychee & Tangerine & & \\
\hline Currant & Prune & & & & \\
\hline
\end{tabular}

*Produk yang sensitive terhadap etilen

Sumber : Thompson (1995).

Prinsip dasar pendinginan pada buah adalah mendapatkan laju penurunan suhu yang cepat untuk menangani produk segar. Laju pendinginan ditentukan oleh perbedaan suhu antar produk dan media pendingin, waktu yang dibutuhkan untuk proses media pendingin dan produk, konduktivitas termal dari produk dan kemasan suatu produk. Media pendingin dalam teknik pendinginan dapat berupa udara, air, evaporasi air dan es. Adapun teknik pendinginan precooling yang dapat diterapkan pada buah pasca panen adalah sebagai berikut . a. Pendinginan ruang (room cooling).

b. Pendinginan dengan tekanan udara (forced-air cooling).

c. Pendinginan dengan air (hydrocooling).

d. Pendinginan vakum (vacuum cooling).

e. Pendinginan menggunakan es batu (package icing).

\section{Waktu Pendinginan 7/8}

Laju pendinginan pada produk pertanian dengan menggunakan precooling digambarkan dengan laju pendinginan 7/8 waktu pendinginan. Laju pendinginan diaplikasikan dalam industri atau sebagai standar pendinginan komersial, produk kemudian disimpan pada penyimpanan dingin (cold storage) yang suhunya disesuaikan dengan karasteristik dari bahan. Kelembaban nisbi penyimpanan dingin untuk produk pertanian perlu dijaga pada kisaran 85 - 95\% apabila lebih dari tujuh hari (Thompson et al., 1998).

Laju pendinginan tiga kali lebih lama dari setengah waktu yang diperlukan untuk mendinginan produk, dengan mengetahui laju pendinginan maka kebutuhan dan waktu yang diperlukan untuk mendinginkan produk sebelum dipasarkan dapat ditentukan (Thompson et al., 1998).

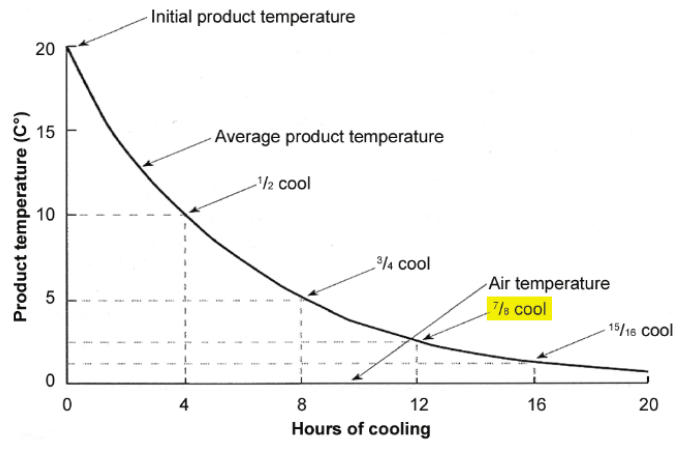

Gambar 1. Laju pendinginan

Gambar 1 menunjukkan laju pendinginan pada jagung yang dipanen pada suhu $95^{\circ} \mathrm{F}$ dan harus didinginkan sampai suhu $32^{\circ} \mathrm{F}$, setengah dari waktu pendinginan adalah $63,5^{\circ} \mathrm{F}$. Laju pendinginan pada jagung adalah waktu $7 / 8$ pada kisaran 12 jam yang berarti panas pada produk telah didinginkan sebesar 87,5 persen. 


\section{Kualitas Bahan Pertanian Pasca Panen}

Buah pasca panen berdasarkan aktivitas respirasi digolongkan menjadi buah klimaterik dan buah non klimaterik. Buah klimaterik adalah kelompok buah yang masih melakukan proses pematangan secara cepat setelah panen, aktivitas respirasi pada buah klimaterik akan menurun seiring meningkatnya kematangan buah hingga mencapai kematangan optimal, sedangkan buah non-klimaterik masih melakukan aktivitas metabolisme yang berlangsung lambat atau tidak mengalami pematangan setelah panen, aktivitas respirasi buah non-klimaterik perlahan akan meningkat seiring tingkat kematangan dan menurun setelah kelewat matang (Khatir, 2009).

Kualitas produk hasil pertanian setelah panen tidak bisa ditingkatkan tetapi dapat dipertahankan dengan penanganan pasca panen yang tepat. Hal ini bertujuan untuk memperpanjang masa simpan produk. Umumnya petani menentukan waktu panen sesuai dengan indikator kenampakan visual (warna) dan fisik. Selain itu menurut Pantastico (1997), pada beberapa hasil pertanian kematangan buah ditentukan berdasarkan densitas.

Sifat fisik hasil pertanian merupakan faktor yang penting dalam penanganan pasca panen diantaranya pengembangan dan rancang bangun alat, analisa perilaku produk dan penanganannya, perhitungan energi selama proses pendinginan dan pengeringan, distribusi, penyimpanan, dan lain sebagainya (Suharto, 2011).

Perubahan fisik dan kimia pada buah selama proses pematangan diakibatkan oleh proses hidrolisis atau pemecahan klorofil, pati, pektin dan komponen penyusun bahan pertanian (Dinarwi, 2013).

\section{Sifat Fisik Bahan Pertanian}

Adapun sifat fisik bahan pertanian diantaranya adalah sebagai berikut :
a. Warna
b. Bobot
c. Volume
d. Densitas

e. Luas Permukaan

f. Kadar Air

\section{Sifat Kimia}

Adapun sifat fisik bahan pertanian diantaranya adalah sebagai berikut

a. Total Padatan Terlarut

\section{METODE PENELITIAN}

\section{Waktu dan Tempat}

Penelitian ini dilakukan pada bulan Februari 2017 di Laboratorium Mekanika Fluida dan Hidrologi Program Studi Keteknikan Pertanian, Fakultas Pertanian, Universitas Hasanuddin, Makassar.

\section{Alat dan Bahan}

Alat yang digunakan dalam peAnelitian ini antara lain : Termocouple, colorimeter, hidrocooler, refractometer, timbangan digital, gelas ukur, jangka sorong, pisau, kamera, dan laptop.

Bahan yang digunakan dalam penelitian ini antara lain : buah terung belanda yang dipetik langsung kematangan yang berbeda, air, es, dan aluminium foil.

\section{Parameter Pengukuran}

Adapun parameter yang diukur dalam penelitian ini adalah sebagai berikut.

1. Sifat fisik dan sifat kimia bahan

2. Sebaran suhu

Sebaran suhu ditentukan pada empat titik pengamatan yakni :

1. Suhu pada sekitar permukaan buah sebagai $t 1$.

2. Suhu pada seperempat daging buah sebagai $t 2$.

3. Suhu pada pusat buah sebagai t3.

4. Suhu air(coolant) sebagai 4 .

\section{Prosedur Penelitian}

a. Persiapan bahan

1. Buah yang digunakan adalah buah terung belanda yang berasal dari kabupaten Toraja Utara dengan tingkat kematangan yang berbeda yakni buah mengkal, matang 
optimum dan matang berlebih yang dipetik langsung dari pohonnya.

2. Membersihkan buah dari kotoran dan benda asing.

b. Sifat Fisik

1. Mengukur diameter buah menggunakan jangka sorong.

2. Menimbang bobot buah.

3. Menentukan nilai warna LAB

4. Mengukur volume.

c. Distribusi suhu

1. Menambahkan es dan air pada alat hydrocooler.

2. Menyalakan pompa untuk menstabilkan suhu dalam hydrocooler hingga mencapai suhu konstan pada $7^{\circ} \mathrm{C}$.

3. Menghubungkan sensor termocouple pada permukaan buah (T1), seperempat ke dalam daging buah (T2), dan pusat buah (T3).

4. Memasukkan buah kedalam hydrocooler.

5. Mencatat nilai yang tertera pada sensor termocouple setiap menit hingga mencapai suhu konstan pada buah pada $7^{\circ} \mathrm{C}$.

6. Mengeluarkan buah dari hidrocooler.

7. Menimbang bobot buah.

8. Mengulangi prosedur 3-7 pada tingkat kematangan yang berbeda.

d. Sifat Kimia

a. Kadar air

1. Menghaluskan buah hingga didapatkan ukuran yang lebih kecil.

2. Menimbang cawan aluminium foil.

3. Menimbang bobot buah beserta cawan.

4. Memasukkan cawan beserta bahan ke dalam oven pada suhu $105^{\circ} \mathrm{C}$ selama 10 jam.

5. Menimbang bahan beserta cawan.

b. Total padatan terlarut

1. Menghaluskan daging buah.
2. Meneteskan sampel pada prisma refraktrometer, membaca hasil yang tertera pada refraktometer.

3. Membersihkan prisma refrakto meter.

4. Mengulangi pengukuran pada sampel yang berbeda.

5. Melakukan analisa data.

6. Membuat laporan hasil penelitian.

\section{Diagram Alir}

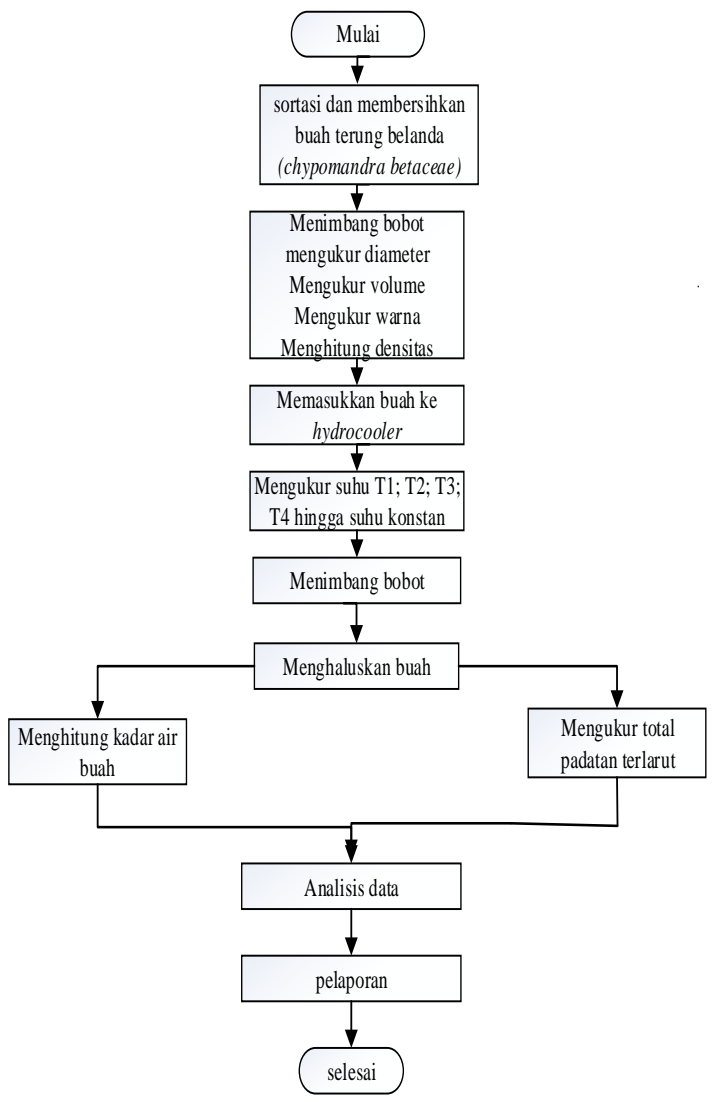

Gambar 2. Bagan alir penelitian

HASIL DAN PEMBAHASAN

\section{Sifat Fisik dan Sifat Kimia Bahan}

Berdasarkan pengukuran yang dilakukan terhadap sifat fisik dan sifat kimia buah terung belanda maka diperolehhasil seperti tabel sebagai berikut.

Tabel 3.Pengukuran sifat fisik dan kimia buah terung belanda.

\begin{tabular}{|c|l|c|c|}
\hline \multirow{2}{*}{ Parameter } & Mengkal & $\begin{array}{c}\text { Matan } \\
\mathrm{g}\end{array}$ & $\begin{array}{c}\text { Matan } \\
\mathrm{g} \\
\text { optima } \\
\text { berlebi } \\
\mathrm{h}\end{array}$ \\
\hline
\end{tabular}




\begin{tabular}{|c|c|r|r|r|} 
& Warna & 58,58 & 43,42 & 38,44 \\
\cline { 2 - 5 } & $\begin{array}{c}\text { Densitas } \\
\left(\mathrm{kg} / \mathrm{m}^{3}\right)\end{array}$ & 1007,49 & 058,40 & 1033,16 \\
\cline { 2 - 5 } $\begin{array}{c}\text { Sifat } \\
\text { fisik }\end{array}$ & $\begin{array}{c}\text { Diameter } \\
\text { mayor } \\
(\mathrm{cm})\end{array}$ & 5,82 & 6,72 & 5,96 \\
\cline { 2 - 5 } & $\begin{array}{c}\text { Luas } \\
\text { permukaa } \\
\mathrm{n}\left(\mathrm{cm}^{2}\right)\end{array}$ & 17,71 & 22,89 & 19,3 \\
\hline $\begin{array}{c}\text { Kadar air } \\
(\%)\end{array}$ & 82,40 & 83,20 & 85,22 \\
\hline $\begin{array}{c}\text { Sifat } \\
\text { kimi } \\
\text { a }\end{array}$ & $\begin{array}{c}\text { TPT } \\
\left({ }^{\circ} \text { brix }\right)\end{array}$ & 10,13 & 12 & 10,80 \\
\hline
\end{tabular}

Tabel 3 menunjukkan pengukuran yang dilakukan terhadap sifat fisik yang meliputi densitas, diameter, luas permukaan dan kadar air serta sifat kimia berupa total padatan terlarut dalam buah.

Berdasarkan pengukuran warna pada buah dapat diketahui bahwa terjadi perbedaan warna dari mengkal hingga matang berlebih. Kandungan warna hijau terus menurun dan kandungan warna merah terus meningkat seiring dengan kematangan buah. Hal ini sesuai dengan pendapat ElZeftawi (1988), yang menyatakan bahwa selama proses pemasakan terjadi perubahan warna dari warna kulit buah terung belanda dari hijau menjadi merah akibat degradasi klorofil dan sintesa pigmen antosianin sehingga warna kulit dapat dijadikan sebagai indikator kematangan pada buah.

Berdasarkan pengukuran yang dilakukan terhadap densitas maka dapat diketahui bahwa tingkat kematangan optimal memiliki nilai densitas yang lebih tinggi dibandingkan densitas pada buah mengkal dan buah matang berlebih. Hal ini sesuai dengan pendapat Pantastico (1989), bahwa densitas buah akan meningkat seiring dengan kematangan buah akibat perombakan yang terjadi pada buah. Menurunnya nilai densitas pada buah matang berlebih diakibatkan oleh meningkatnya kadar air dalam buah.

$$
\text { Pengukuran diameter buah }
$$

dilakukan untuk menentukan letak atau titik pengukuran suhu pada buah. Letak pusat buah ditentukan dengan setengah dari diameter mayor buah terhitung dari pangkalatau ujung buah. Seperempat daging buah ditentukan dengan seperempat dikalikan dengan diameter mayor terhitung dari pangkal atau ujung buah dan letak titik sekitar permukaan buah merupakan $1 \mathrm{~cm}$ ke dalam buah terhitung dari pangkal atau ujung buah.

Luas permukaan buah merupakan salah satu faktor yang menentukan kecepatan dalam pendinginan maupun pengeringan pada bahan pertanian. Luas permukaan bahan yang lebih besar memungkinkan untuk sebaran suhu yang lebih cepat dibandingkan dengan bahan yang memiliki luas permukaan yang lebih kecil.

Kadar air mengalami peningkatan seiring dengan pematangan yang diakibatkan oleh proses metabolisme pada buah, hal ini sesuai dengan pendapat Syarif dan Halid (1993), bahwa kadar air buah mengalami peningkatan selama proses pematangan yang disebabkan oleh kegiatan respirasi dari tangkai hingga daging buah lebih dominan dibandingkan proses transpirasi dan hidrolisis pati.

Total padatan terlarut meningkat seiring kematangan buah dan mengalami penurunan ketika buah matang berlebih akibat respirasi yang terjadi pada buah. Hal ini sesuai dengan pendapat Calvin dan Donald (1983), bahwa selama respirasi terjadi penurunan kadar gula dan komponen lainnya seiring terbentuknya karbondioksida, air, energi dan panas. Energi terbentuk melalui aktivitas sel selama proses pematangan yang terjadi.

\section{Bobot}

Berdasarkan pengukuran yang dilakukan terhadap bobot pada buah terung belanda (Chypomandra betacea) dengan berbagai tingkat kematangan maka diperoleh hasil pada gambar 4.1. 


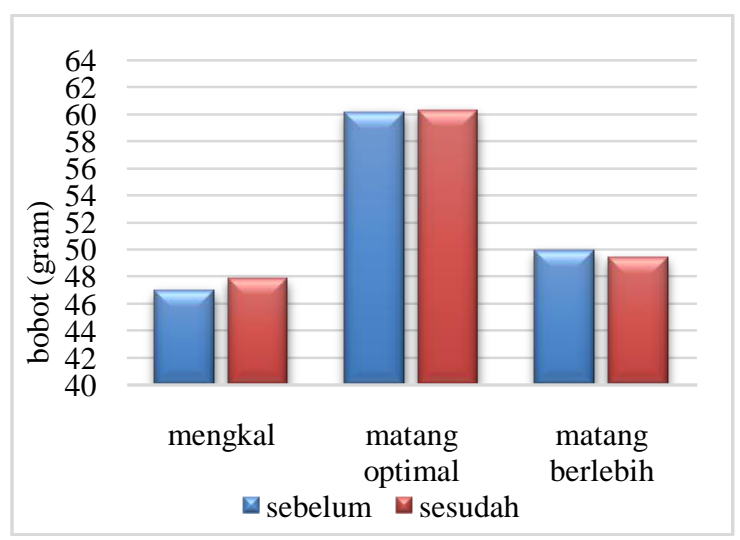

Gambar 3. Bobot buah

Gambar 3 menunjukkan grafik perbedaan bobot sebelum dan sesudah buah di beri perlakuan hydrocooling.Pada buah mengkal dan matang optimal terjadi difusi atau penyerapan air dengan adanya penambahan bobot setelah dilakukan proses hydrocooling, sedangkan pada buah matang berlebih terjadi penurunan bobot atau kehilangan sebagian air pada proses hydrocooling, hal ini dikarenakan kandungan air yang besar dalam buah matang berlebih berkurang pada saat sensor ditancapkan ke dalam buah.

\section{Sebaran suhu}

1. Sebaran suhu pada buah

Berdasarkan pengukuran yang dilakukan terhadap suhu pada buah terung belanda (Chypomandra betacea) dengan tingkat kematangan berbeda maka diperoleh hasil sebagai berikut.

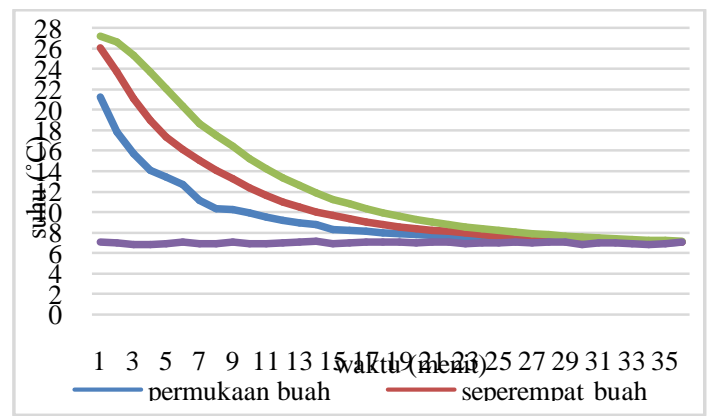

Gambar 4. Sebaran suhu pada buah mengkal.

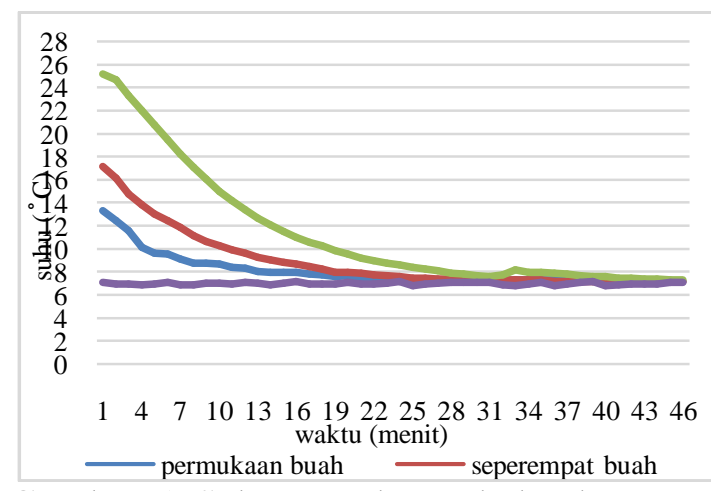

Gambar 5. Sebaran suhu pada buah matang optimal

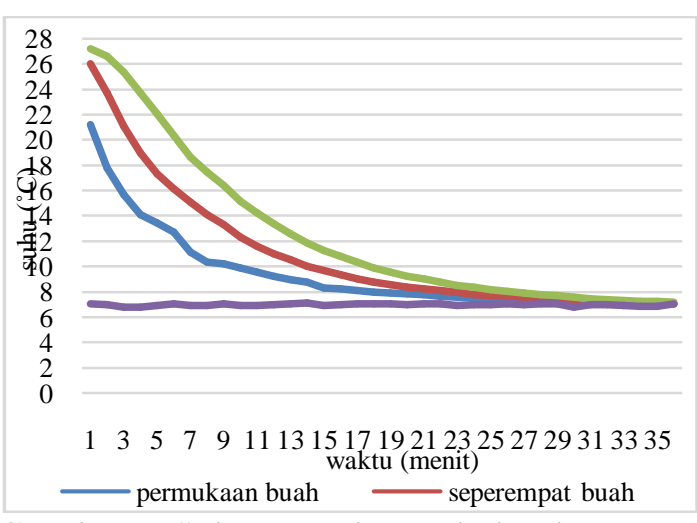

Gambar 6.Sebaran suhu pada buah matang berlebih

Gambar 4 menunjukkan grafik hubungan antara waktu yang diperlukan untuk mencapai suhu konstan sebesar $7^{\circ} \mathrm{C}$ pada permukaan buah, seperempat buah dan pusat buah. Buah mengkal membutuhkan waktu selama 43 menit untuk mencapai suhu konstan. Buah matang optimal membutuhkan waktu selama 56 menit untuk mencapai suhu konstan (gambar 5) dan buah matang berlebih membuthkan waktu selama 36 menit untuk mencapai suhu konstan (gambar 6).

2. Sebaran suhu pada titik buah

Berdasarkan pengukuran yang dilakukan terhadap sebaran suhu pada sekitar permukaan, seperempat daging dan pusat buah terung belanda (Chypomandra betacea) dengan berbagai tingkat kematangan maka diperoleh hasil sebagai berikut. 


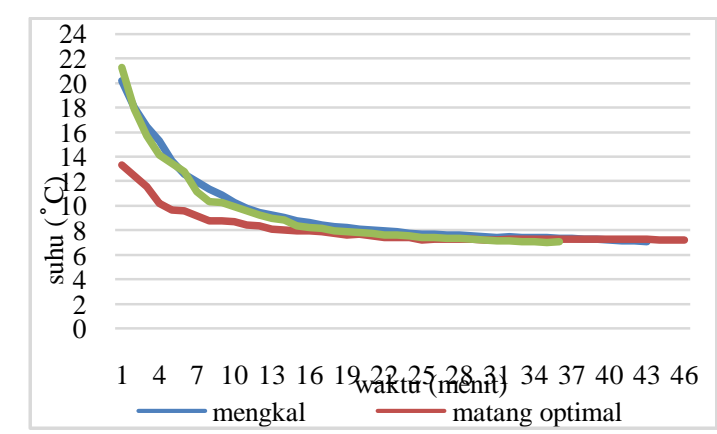

Gambar 7.Sebaran suhu pada sekitar permukaan buah

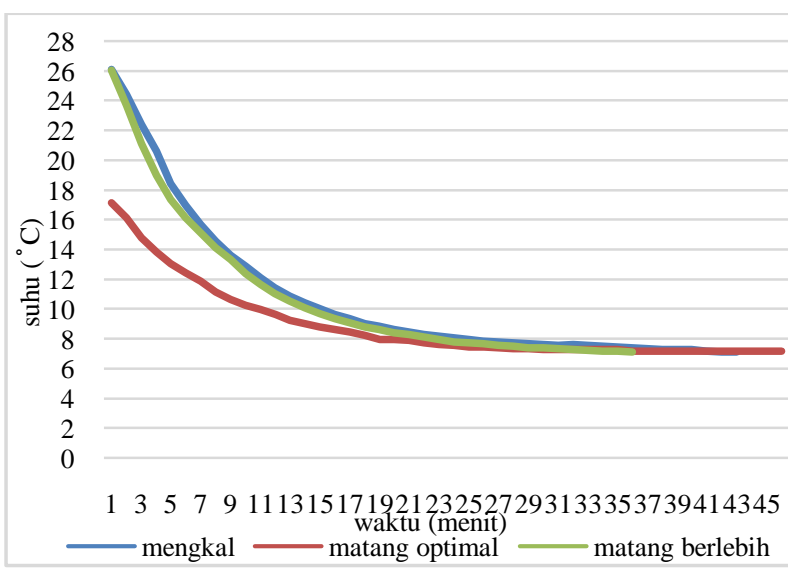

Gambar 8. Sebaran suhu pada seperempat daging buah

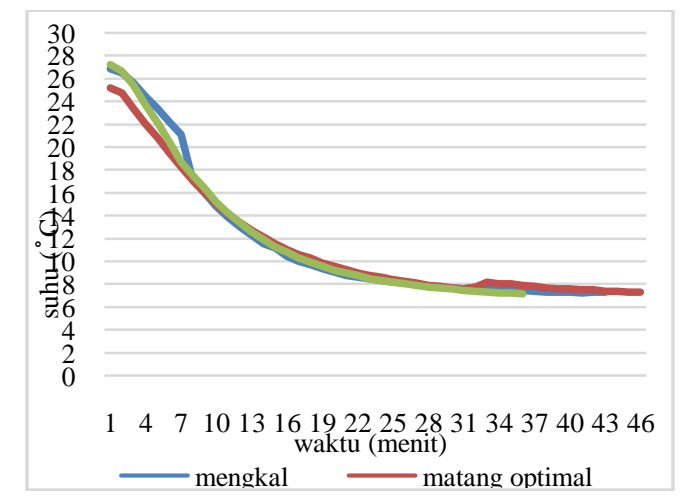

Gambar 9. Sebaran suhu pada pusat buah

Gambar 7 menunjukkan grafik hubungan waktu yang diperlukan untuk mencapai suhu konstan sebesar $7^{0} \mathrm{C}$ pada sekitar permukaan buah dengan berbagai tingkat kematangan. Pada menit ke-15, masing-masing permukaan buah telah mencapai suhu $8^{\circ} \mathrm{C}$.

Gambar 8 menunjukkan grafik hubungan waktu yang diperlukan untuk mencapai suhu konstan sebesar $7^{0} \mathrm{C}$ pada seperempat daging buah dengan berbagai tingkat kematangan. Pada menit ke 20 suhu pada masing-masing buah mencapai $8^{\circ} \mathrm{C}$.
Gambar 9 menunjukkan grafik hubungan waktu yang diperlukan untuk mencapai suhu konstan sebesar $7^{0} \mathrm{C}$ pada pusat buah dengan berbagai tingkat kematangan. Grafik penurunan suhu pada buah dengan berbagai tingkat kematangan tidak terlalu jauh berbeda. Suhu menit pertama untuk masingmasing buah berkisar antara $25-27^{\circ} \mathrm{C}$ dan mencapai suhu $7^{\circ} \mathrm{C}$ pada menit ke 30 . Hal ini sesuai dengan pendapat Kitinoja dan Kader (2002), yang menyatakan bahwa pendinginan dengan teknik hydrocooling menggunakan air sebagai konduktor panas yang baik karena mampu menurunkan suhu produk yang berkisar hingga suhu $35^{\circ} \mathrm{C}$ mendekati suhu penyimpanan sebesar $5^{\circ} \mathrm{C}$ secara cepat dalam rentang waktu 15 menit hingga 45 menit.

Pada buah matang optimal lebih cepat mengalami penurunan suhu dikarenakan luas permukaan buah lebih besar dibandingkan dengan buah mengkal dan matang berlebih, sedangkan pada buah mengkal dan matang laju sebaran suhu hampir sama. Buah matang optimal membutuhkan waktu yang lebih lama untuk mencapai suhu konstan, hal ini dikarenakan densitas pada buah matang optimal lebih tinggi daripada buah mengkal dan buah matang berlebih, hal ini sesuai dengan pendapat Pantastico (1989), yang menyatakan bahwa pada pemasakan buah zat-zat terlarut akan bertambah seiring dengan pematangan buah yang mengakibatkan bobot jenis bertambah.

\section{Laju Pendinginan}

Berdasarkan perhitungan yang dilakukan terhadap laju pendinginan pada sekitar permukaan, seperempat daging dan pusat buah terung belanda (Chypomandra betacea) dengan berbagai tingkat kematangan maka diperoleh hasil sebagai berikut. 


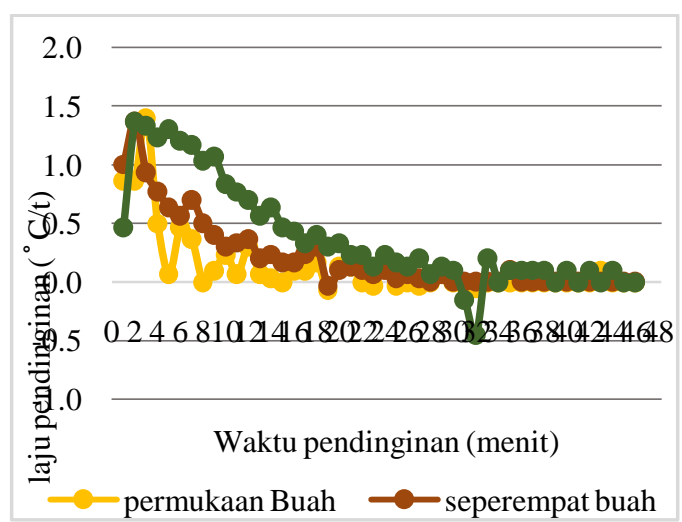

Gambar 4.8 Laju pendinginan pada buah mengkal

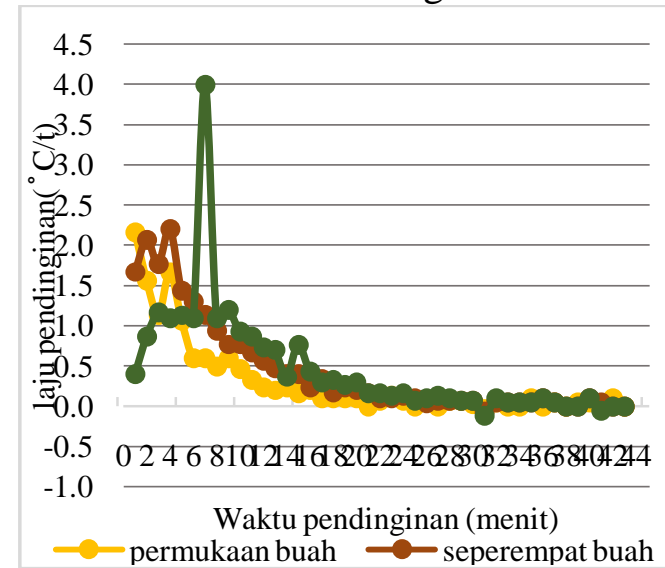

Gambar 4.9 Laju pendinginan pada buah matang optimal

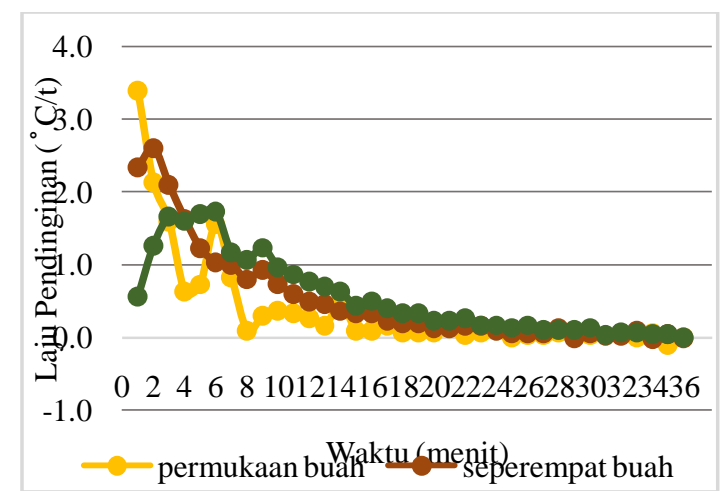

Gambar 4.10 Laju pendinginan pada buah matang berlebih

Gambar 4.8 menunjukkan grafik laju pendinginan terhadap buah mengkal untuk mencapai suhu pendinginan sebesar $7^{\circ} \mathrm{C}$. Untuk mencapai suhu pendinginan dibutuhkan waktu selama 43 menit. Pada menit ke-7, laju suhu pada pusat buah cukup tinggi yakni sebesar $4^{\circ} \mathrm{C}$. Hal ini dikarenakan adanya penambahan es selama proses pendinginanpada saat suhu coolant masih stabil pada $7^{\circ} \mathrm{C}$.
Gambar 4.9 menunjukkan grafik laju pendinginan pada buah matang optimal selama 46 menit untuk mencapai suhu pendinginan. Pada menit pertama suhu mengalami penurunan sebesar $1{ }^{\circ} \mathrm{C}$ dan berangsur-angsur hingga mencapai suhu pendinginan. Laju pendinginan pada permukaan buah, seperempat daging buah dan pusat tidak terlalu berbeda.

Gambar 4.10 menunjukkan grafik laju pendinginan pada buah matang berlebih selama 36 menit untuk mencapai suhu pendinginan. Pada menit pertama hingga menit ke-3, laju suhu pada pendinginan pada permukaan buah dan seperempat daging buah cukup tinggi yakni sebesar $3^{\circ} \mathrm{C}$ dan $2^{\circ} \mathrm{C}$ kemudian berangsur-angsur stabil pada menit ke-9 hingga mencapai suhu pendinginan. Laju pendinginan pada permukaan buah, seperempat daging buah dan pusat buah memiliki nilai yang tidak terlalu berbeda.

\section{Waktu pendinginan $7 / 8$}

Berdasarkan perhitungan yang dilakukan terhadap waktu pendinginan 7/8 pada buah terung belanda (Chypomandra betacea) dengan tingkat kematangan, maka diperoleh hasil sebagai berikut.

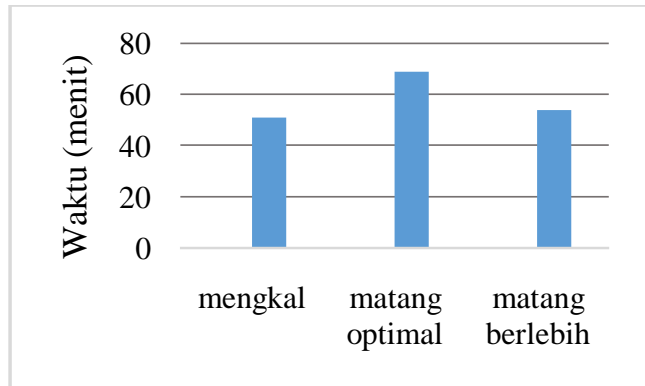

Gambar 4.11 Waktu pendinginan 7/8 pada buah

Berdasarkan grafik 4.11 waktu pendinginan $7 / 8$ dapat diketahui bahwa buah matang optimal membutuhkan waktu pendinginan yang lebih lama untuk mencapai waktu $7 / 8$ pendinginan hal ini dikarenakan buah matang optimal memiliki diameter yang lebih besar daripada buah mengkal dan buah matang berlebih. 


\section{KESIMPULAN DAN SARAN}

\section{Kesimpulan}

1. Sebaran suhu pada buah mengkal membutuhkan waktu selama 43 menit, matang optimal selama 56 dan matang berlebih selama 36 menit untuk mencapai suhu konstan sebesar $7^{\circ} \mathrm{C}$.

2. Bobot buah sebelum dan sesudah perlakuan hydrocooling tidak jauh berbeda. Bobot buah mengkal dan matang optimal meningkat sebesar $0,01 \%$ dan matang berlebih menurun sebesar $0,01 \%$.

3. Waktu pendinginan $7 / 8$ pada buah mengkal selama 51 menit, pada buah matang optimal selama 69 menit dan pada buah matang berlebih selama 54 menit.

\section{Saran}

Sebaiknya dilakukan pengamatan atau penelitian lebih lanjut tentang pengaruh hydrocooling terhadap umur simpan buah terung belanda (Chypomandra betacea) baik pada suhu ruang maupun pada lingkungan terkendali yang meliputi pengamatan sifat fisik dan kimia buah dalam rentang waktu penyimpanan.

\section{DAFTAR PUSTAKA}

Anonim, 2013. Peraturan Menteri Pertanian Republik Indonesia Nomor 73/Permentan/Ot.140/7/2013 Tentang Pedoman Panen, Pascapanen, dan Pengelolaan Bangsal Pascapanen Hortikultura yang Baik.

Astuti. 2007. Petunjuk Praktikum Analisis Bahan Biologi. Yogyakarta: Jurdik Biologi FMIPA UNY.

Becker, Israel B.R. and B.A. Fricke. Hydrocoling time estimation methods. Intl. Commun. Heat Mas Transfer.

Buckle, K.A. 1985. Ilmu Pangan. Jakarta: UI press.

Bueche, Frederick J. And Eugene Hecht. 2006. Fisika Universitas. Jakarta: Erlangga.
Calvin, C.L dan Donald, M.K. 1983. Modern Home Gardening. Portland State University, New York.

Departemen Kesehatan Republik Indonesia. 2000. Parameter Standar Umum Ekstrak Tumbuhan Obat. Direktorat Jendral Pengawasan Obat dan Makanan. Jakarta.

Dinarwi. 2013. Pengaruh Penggunaan Gas Oksigen dan Karbondioksida Terhadap Umur Simpan Buah Mangga. Berita Litbang Industri. Volume XXXIX No.1.

Dwidjoseputro, D. 1990. Dasar-Dasar Mikrobiologi. Jakarta: Djambatan.

El-Zaftawi, B.M., Brohier, L., Doodly, L., Goubran, F.H., Holmes, R. And Scott, B., 1988. Some Maturity Indices for Tamarillo and Pepino Fruits. J. Hortic.

Hardiyanti, N., E.J. Kining, Fauziah Ahmad, and N.M Ningsih . 2009. Warna Alami. Jurusan Geografi. Fakultas Matematika dan Ilmu Pengetahuan Alam.Universitas Negri Makassar

Heldman, DR dan Darryl B. Lund. 2007. Handbook of Engineering . Edisi Ke 2. CRC Press.

Holinesti, Rahmi. 2009. Studi Pemanfaatan Pigmen Brazilein Kayu Secang (Caesalpinia Sappan L) Sebagai Pewarna Alami dan Stabilitasnya pada Model Pangan. Jurnal Pendidikan dan Keluarga UNP, Vol.1, No.2.

Hunterlab, 2008. CIE L* $a^{*} b^{*}$ Color Scale vol 8. No. 7. http//:Hunterlab.com, diakses pada September 2016.

Kasmire, R.F. and Parsons, R.A. 1971. "Precooling cantaloupes, a shipper's guide". Agric. Ext. Service, University of California, Berkeley.

Kassama. 2003. Structural And Instrumental Textural Properties Of Meat Patties Containing Soy Protein. International Journal of Food Properties.

Khatir Rita, 2009. Penuntun Praktikum Fisiologi dan Penanganan Pasca Panen. Faperta_UNSYIAH, Banda Aceh. 
Kitinoja Lisa. and Kader Adel, A. 2003. Small-Scale Postharvest Practices: A Manual for Horticultural Crops, 4th edition. University of California, Davis.

Kumalaningsih Sri, 2006. Antioksidan Alami-Penangkal Radikal Bebas, Sumber, Manfaat, Cara Penyediaan dan Pengolahan. Surabaya: Trubus Agrisarana.

Pangestuti, R. 2004. Pengaruh Suhu Penyimpanan Terhadap Perubahan Kualitas Dan Umur Simpan Buah Jeruk Keprok Soe (Citrus Reticulata Blanco) Pada Umur Petik Yang Berbeda. Balai Penelitian Tanaman Jeruk Dan Buah Subtropika. Nusa Tenggara Timur.

Pantastico, Er. 1997. Fisiologi Pasca Panen; Penanganan dan Pemanfaatan Buah-Buahan dan Sayur-Sayuran Tropika Dan Subtropika. UGM-Press Yogyakarta.

Sabliov, Dkk. 2002. Image Processing Method To Determine Surface Area And Volume Of Axi-Symmetric Agricultural Products. International Journal Of Food Properties.

Sandjaja dan Atmarita. 2009. Kamus gizi pelengkap kesehatan keluarga. PT. Kompas Media Nusantara. Jakarta.

Singh, R. Paul and Dennis R. Heldman, 2009. Introduction to Food Engineering. Academic Press, Elsevier.

Suharto, 2011. Teknologi Pengawetan Pangan. PT.Rineka Cipta, Jakarta

Syarief, R. dan H. Halid. 1993. Teknologi Penyimpanan Pangan. Arcan, Jakarta.

Tarigan,S and Pintubatu. 2006. Perbanyakan Bibit Terong Berastagi (Chiphomandra Betaceae) dengan Tekhnik Penyambungan Batang Bawah (onderstam) Tanaman Rimbang ( Solanum Torvum SW) dan Budidaya. Kopertis SUMUTNAD. Medan. ISBN 978-979-1115-30-8.

Thompson, J.F., Kader, A.A and Sylva, K. 1995. Compatibility Chart for Fruits and Vegetables in Short-term Transport or Storage. University of California DANR Publication.
Utama, I M. S, I. A. R. Pratiwi Puja, and E.E. Wijayanti. 2006.The effects of delay of precooling on the Visual Quality of Broccoli During Storage Iced-Styrofoam Box. Poster presented on the National Seminar on The Importance of Postharvest Technology in Escalating Competitiveness of Indonesia's Horticultural Products.

Utama, I M.S. 2007. The Horticulture Value Chain Assessment in Eastern Indonesia:Findings, Recommendations, Proposed Interventions. A presentation given to the Workshop on "Agribusiness Value Chains: Assessments, Recommendations, and Proposed Interventions in Eastern Indonesia" Conducted by AMARTAUSAID at Intercontinental Bali Resort, Bali.

Verheij, E.M.W. danR.E. Coronel, 1997. Sumber Daya Nabati Asia Tenggara, Buah-buahan yang Dapat Dimakan. Terjemahan S. Somaatmadja. Gramedia Pustaka Utama, Jakarta.

Wardani, E.W.B. 2013. Identifikasi Sifat Fisik Buah Nangka (Artocarpus heterophyllus). Jurnal Keteknikan Pertanian Tropis dan Biosistem Vol. 1 No. 3. Malang.

Winarno, F.G. dan Betty Sri. 1982. Kerusakan Bahan Pangan dan Cara Pencegahannya. Ghalia Indonesia, Bogor. 